\title{
In searching the appropriate elements: study on the community's environmental friendly behavior in daily activities to achieve an urban sustainability
}

\author{
Dhywa Darmawan ${ }^{1}$, Wustari Larasati Mangundjaya ${ }^{2, *}$, and Herdis Herdiansyah ${ }^{1}$ \\ ${ }^{1}$ School of Environmental Science, University of Indonesia, Jakarta, Indonesia \\ ${ }^{2}$ Faculty of Psychology, University of Indonesia, Depok, Indonesia
}

\begin{abstract}
Environmentally friendly behavior has become an important part in achieving sustainable city. However, the implementation of environmentally friendly behavior in daily activities tends to get low participation. Therefore, this study aims to find out the factors that influence a person to behave in an environmentally friendly manner, especially from social and psychological aspects. This study using literature review and weighting based pairwise comparison as a method. Our study concluded, there are four groups of factors that influence the community in implementing environmental friendly behaviors, namely: internal factor (environmental knowledge and attitude), external factor (support from the government in providing environmental education, public facilities, and establish environmental policies and regulations), socio-demographic factor, and situational factor (financial aspects and the availability of good facilities/green product). Furthermore, external factors (such as government support in providing environmental education and public facilities) is the factor that most influence environmentally friendly behavior and also as a key factor in achieving a sustainable city.
\end{abstract}

\section{Introduction}

The decreased quality of the urban environment is an environmental issue that always threatens all countries in the world, where this issue is related to pollution of air, water, soil, and rising temperatures on the surface of the earth [43]. The declining quality of urban environments in developing countries has been a public debate in sustainable development mainly related to the concept of a sustainable city (SDGS No. 11 Sustainable Cities and Communities) [4]. Urban environments that are not in sustainable conditions will threaten the lives of humankind, cause more than $50 \%$ of the world's human population lives in urban areas, and it is estimated about $60 \%$ of the world's human population will live in urban areas in $2030[19,36,42]$. The decline in urban environmental quality is directly caused by human behavior [7, 28, 37]. Human daily activities have contributed to the deterioration of environmental quality, and it is estimated that this contribution will get bigger along with the

\footnotetext{
${ }^{*}$ Corresponding author: wustari@gmail.com
} 
increasing human population in the environment $[8,17,24]$. Therefore, it is necessary to change people's behavior toward the environment to achieve sustainable development [36, 37].

Applying the lifestyle-based ecological and sustainable principles through everyday activities is an important element to achieve sustainable city, and this principle has become a new agenda across countries [5]. There are several principles of change that must be applied, but in general human behavior must use resources efficiently and human behavior must avoid activities that contribute negatively to the environment [34]. This behavioral principle is related to environmentally friendly behavior, the environmentally friendly behavior is a behavior that refers to minimize the negative effects of an activity on the environment, and this behavior also contributes to preserving the environment $[2,21,23,36]$. Behavioral changes in environmental care will have a faster and positive impact on environmental sustainability when compared to technological innovations [23, 37].

The importance of implementing the environmentally friendly behavior in achieving a sustainable city has raised questions about how to increase community participation in implementing this behavior, considering the application of environmentally friendly behavior in developing countries tends to get low participation by the community [29, 33, 43]. To overcome this problem, this study will investigate: 1) what factors influence environmentally friendly behavior and 2) reveal the factors that most influence environmentally friendly behavior. Furthermore, this study will explain systematically in understanding environmentally friendly behavior.

\section{Methods}

The method in this study uses a literature review with a systematic review approach and weighting based pairwise comparison. The systematic review method will improve and expand the author's understanding of the topic of environmentally friendly behavior, the factors that influence environmentally friendly behavior, and also the of role environmentally friendly behavior in sustainable development that has been written by the previous study. To get information related to environmentally friendly behavior, this study uses sources and information with a high scientific level, such as a Scopus-index journal, other supporting journals, and books. Furthermore, to facilitate the search for articles related to research topics, the search terms used are: 'pro-environmental behavior' and 'environmental citizenship'.

After reviewing journal that has related keywords, then the author considers using articles/book that provides important points or information about environmentally friendly behavior as the study material. Furthermore, the information that has been obtained based on literature studies will be presented descriptively and arranged systematically. Besides, a concept model will be formed in this study that aims to understand environmentally friendly behavior so well.

Table 1. Pairwise values criteria.

\begin{tabular}{|c|c|}
\hline Value & Definition \\
\hline 1 & two factor is equally important \\
\hline 3 & one factor is a little more important \\
\hline 5 & one factor is a more important \\
\hline 7 & one factor is very important \\
\hline 9 & one factor is important \\
\hline
\end{tabular}

Every factor that influences environmentally friendly behavior will be analyzed by weighting methods to estimate which factors influence the most this behavior. The weighting of each factor is done by pairwise comparisons where two factor will be evaluated based on 
their relative importance on environmentally friendly behavior with the pairwise values criteria (see Table. 1). After the factor is given an assessment based on the comparison of interests, the principle of a normalizing eigenvector is used to obtain the weighting/priority value so the factors that most influence the environmentally friendly behavior will be revealed based on the value of the weight possessed by the factor.

\section{Result and discussions}

\subsection{Environmentally friendly behavior as an element on sustainable city}

A pleasant and sustainable city is an achievement that every city wants to achieve. To achieve a sustainable city some experts have explained several aspects that must be considered, that is: 1) urban form, 2) energy use and waste management, 3) transportation, and 4) urban ecology and biodiversity $[5,25]$. However, several studies explain the new dimensions of a sustainable city, that is: a city must be inhabited by environmental citizenship. Environmental citizenship is a type of society that always links environmental issues seriously into an activity and also this society lives by applying sustainable concepts in daily activities so that future generations can live well $[1,5]$.

Environmental citizenship has been recognized as an essential dimension in the concept of a sustainable city, cause without the assistance and support of the community in implementing environmentally friendly lifestyles the efforts to reach a sustainable city will not be achieved [5]. Environmentally friendly behavior carried out in daily activities is a major element in the formation of environmental citizenship. Some studies explain that environmentally friendly behavior in daily activities can be grouped into five categories [5, $12,22]$, that is:

a. Energy conservation: not leaving electronic items in stand-by condition and turn off the lights when there is no activity in the room.

b. Water conservation: use a shower instead of a bathtub, turn off the tap when cleaning the face, washing dishes, or brushing teeth, and wash clothes when the laundry is in full condition only.

c. Waste management: sorting plastic bottles, cans, glass, and paper, composting household waste, and reduce the use of plastic bags and batteries.

d. Mobility and Transportation: use a bicycle or walk if the destination is very close and use public transportation to the office, school, and other destination.

e. Green consumption: buy products with eco-label and buy recycled products (such as paper, tissue, etc.).

\subsection{Factors that influence environmentally friendly behavior}

Understanding the factors that affect environmentally friendly behavior comprehensively is very important, which will give benefit to the efforts to increase community participation in the application of this behavior [23]. Sociologists and psychologists have explained the factors that influence the application of environmentally friendly behavior in households and workplaces setting with different perspective [43]. There are four group factors influence environmentally friendly behavior, that is: 1) internal factors (environmental knowledge and attitude), 2) external factors (support from the government in providing environmental education, public facilities, and establish environmental policies and regulations), 3) demographic factor (gender, age, and education), and 4) situational factors (financial aspects and the availability of facilities) (see Fig. 1) [11,21,27]. However, it is estimated that internal and external factors are factors that can be managed to improve the application of 
environmentally friendly behavior through government policy, so this study only focuses on these two factors [43].

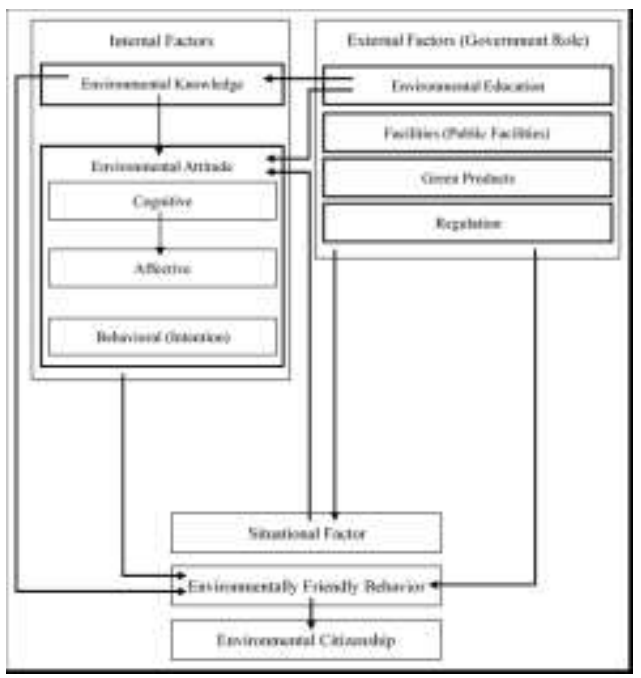

Fig. 1 Conceptual framework for environmentally friendly behavior

\subsubsection{Environmental knowledge}

Several obstacles make a person not apply environmentally friendly behavior, one of the obstacles is the lack of environmental knowledge [9, 35]. Environmental knowledge is defined as general knowledge about the concept of environmental interaction with living things, how the environment works, an understanding of environmental problems, and how environmental problems can arise [13, 16, 26, 32, 43]. Environmental knowledge is an important component in the formation of environmental citizens since environmental knowledge will influence a person's willingness to protect the environment and influence the level of participation of someone in implementing environmentally friendly behavior $[3,6$, $20,35]$. Besides, environmental knowledge also has a positive effect on attitudes, when someone gets environmental knowledge, this will tend to change someone attitude to be more concerned about the environment $[4,43]$.

\subsubsection{Environmental attitudes}

Environmental attitudes are psychological tendencies towards the natural environment and the values of protection contained in the environment that are evaluated at several levels such as agreeing and liking or disagreeing and disliking [41]. Environmental attitudes are an important component in environmental citizenship since this attitude influences someone in implementing environmentally friendly behavior significantly [30, 38]. Besides that, when a good attitude is accompanied by appropriate environmental information will have a positive impact on achieving sustainable city [31].

Understanding the complexity of an attitude will provide benefits in forming environmental citizenship and achieving a sustainable city. To understand the complexity of an attitude, the attitude needs to be divided into three components: a) cognition, b) effect, and c) intention to behave [40]. Cognition is described or believes in something that exists and will trigger a person to have a sense of moral obligation [29, 40]. Affective is the emotional segment that is reflected in a statement, such as positive emotions (happiness, love, and like) 
and negative emotions (anger, fear, dislike, and sadness) [10, 40]. The level of emotion a person has toward a thing is a factor that influences a person's commitment to behave or act [14]. Intention to behave from an attitude explains an intention to behave in a certain way. The strong component of intention to behave will actively describe the behavior that will be carried out by someone [18].

\subsubsection{Environmental education}

Environmental education is considered an important requirement in achieving sustainable development [39]. Environmental education can function as a tool to overcome environmental problems and as an instrument of social transformation in sustainable development, especially in creating communities that have environmentally friendly behavior $[15,39]$. The provision of environmental education by the government to the public is vital since environmental education can increase environmental knowledge and influence one's attitude through a willingness to protect the environment and potentially change someone behavior to be more environmental friendly $[11,15,20]$.

\subsubsection{Public facilities and green products}

Adequate public facilities and green products are one crucial dimension in developing environmental citizenship. The study says that human behavior is not only influenced by intrinsic motivation but many factors can support individual motivation to implement environmental friendly behavior, that is public facilities and green products [23]. The availability of good public facilities and green products have a significant influence on the application of environmentally friendly behavior [23, 43]. Otherwise, if urban areas do not provide comfortable public facilities and green products, this will have a negative impact on the social systems (especially on public interest to act environmentally friendly behavior) [21].

\subsubsection{Government regulation}

Government regulations and policies on the environment are important components in the formation of environmental citizenship. The regulations and policies established by the government will influence a person's behavior and habits. Establishing appropriate regulations and procedures related to environmental protection will have a positive influence on community behavior and community attitudes towards caring for the environment [1]. Some studies argue that through the provision of incentives/rewards or the established of penalties will encourage the community to behave environmentally, for example: the collection of fees for the use of plastic bags will have a positive influence, which is the level of use of shopping bags will increase and then this thing will become a habit in the social system [21].

\subsubsection{Situational factor}

The situational factor can be defined as an individual's condition and motivation at a particular time, represented by access to a matter, knowledge, and experience to carry out an activity, or individual economic circumstances [21, 43]. Some studies concluded that situational factors are factors that have an essential role in determining environmental friendly behavior [21, 43]. This factor often associated with the availability of facilities and green products and regulation/policy. Unavailability or difficulty of access to public facilities 
is an obstacle that makes it difficult for someone to behave environmentally [21]. Furthermore, financial matters can also affect a person to act environmentally. When the government creates regulations related to charging systems for every use of plastic bags, this will slowly shape the individual's intention to carry their shopping bags rather than having to spend money on a single-use plastic bag [21].

\subsubsection{The factors that most influence environmentally friendly}

Environmental education is a factor that has a considerable weight in determining environmental friendly behavior when compared to other factors (see Table. 2). Environmental education has an essential contribution to the formation of environmental friendly civilizations because directly environmental education will increase a person's sense of care for the environment, improve someone's understanding of environmental issues, enhance someone's willingness to protect the environment, and change someone behavior to be more environmentally friendly [6, 11, 20, 29].

Table 2. Weighting factors affecting environmentally friendly behavior.

\begin{tabular}{|l|c|c|c|c|c|c|}
\hline & Knowledge & Attitudes & Education & $\begin{array}{l}\text { Facilities and } \\
\text { Green Product }\end{array}$ & Regulation & $\begin{array}{l}\text { Weight/ } \\
\text { priority }\end{array}$ \\
\hline Knowledge & 1.00 & 0.33 & 0.20 & 0.33 & 0.33 & 0.06 \\
\hline Attitudes & 3.00 & 1.00 & 0.20 & 1.00 & 3.00 & 0.18 \\
\hline Education & 5.00 & 5.00 & 1.00 & 3.00 & 3.00 & 0.46 \\
\hline $\begin{array}{l}\text { Facilities and } \\
\text { Green Product }\end{array}$ & 3.00 & 1.00 & 0.33 & 1.00 & 3.00 & 0.19 \\
\hline Regulation & 3.00 & 0.33 & 0.33 & 0.33 & 1.00 & 0.11 \\
\hline
\end{tabular}

The role of the government in supporting environmentally friendly behavior through the provision of excellent public facilities dan green products shows considerable weight in determining environmentally friendly behavior. The availability and easy access to public facilities/green products are extrinsic motivation which will provide opportunities and choices for the community to implement environmentally friendly behavior [21].

\section{Conclusion}

Environmentally friendly behavior is an important component in developing a sustainable city and environmental civilizations. However, There are several factors that must be considered, namely: a) internal factor (environmental knowledge and environmental attitude), b) external factor (government support through established policies/regulations, provision of public facilities/green product, and environmental education), and c) situational factor so that all levels of society can apply this behavior. Environmental knowledge, environmental attitude, and government support through established policies/regulations (rewards or penalties), provision of public facilities/green product, and environmental education have a significant influence on community participation in implementing environmentally friendly behavior. Furthermore, environmental education and public facilities and green products are the factors that most influence environmentally friendly behavior as well as the factors that most contribute to environmental citizenship and sustainable city.

\section{References}

1. A. Dobson, Sust Dev. 15: 276-285, (2007) 
2. A. Kollmuss, J. Agyemen, Environ Edu Rese. 8(3): 239-260, (2002)

3. A. M. M. Mahidin, S. Maulan, Pro-Soc and Behav Sci. 38: 324- 333, (2012)

4. A. Paco, T. Lavrador, J Environ Manage. 197: 384-392, (2017)

5. B. Asilsoy, D. Oktay, Sust Citi and Soci. 1-26, (2018)

6. C. D'Souza, M. Taghian, P. Lamb, Corp Commu: Intern J. 11(2): 162-173, (2006)

7. C. Vlek, L. Steg, J Soc Issues. 63 (1): 1-19, (2007)

8. E. F. Moran, Environmental Social Science: Human-Environment Interactions and Sustainability. (2010)

9. E. Manolas, AEJES. 1: 13-21, (2015)

10. E. N. M. Nameghi, M. A. Shadi, Intern J Markt Stu. 5(1): 157-164, (2013)

11. E. R. Frederiks, K. Stenner, E. V. Hobman, Energ. 8: 573-609, (2015)

12. F. G. Kaiser, M. Wilson, Person and Indiv Diff. 36(7): 1531-1544, (2004)

13. G. E. Fryxell, C. W. H. Lo, J Busi Eth. 46: 45-69, (2003)

14. H. E. Perkins, J Environ Psyc. 30(4): 455-463, (2010)

15. I. Novo-Corti, M. T. García-Álvarez, L. Varela-Candamio, J Clean Prod. (2017)

16. J. Frick, F. G. Kaiser, M. Wilson, Person and Indiv Diff. 37: 1597-1613, (2004)

17. J. Harte, Popul Environ. 28:223-236, (2007)

18. J. J. Guyer, L. R. Fabrigar, International Encyclopedia of the Social \& Behavioral Sciences (Second Edition), (2015)

19. K. C. Seto, S. Parnell, T. Elmqvist, Urbanization, Biodiversity and Ecosystem Services: Challenges and Opportunities. (2013)

20. K. Kalantari, H. S. Fami, A. Asadi, H. M. Mohammadi, Americ J Environ Sci. 3(2): $67-$ 74, (2007)

21. K. Kurisu, Pro-environmental Behaviors. (2015)

22. L. R. Larson, R. C. Stedman, C. B. Cooper, D. J. Decker, J Environ Psyc. 43: 112-124, (2014)

23. L. Steg, C. Vlek, J Environ Psyc. 29: 309-317, (2009)

24. M. Harish, Manag Res and Prac. 4(3): 25-36, (2012)

25. M. Jenks, C. Jones, Dimensions of the Sustainable City. (2010)

26. M. Laroche, J. Bergeron, G. Barbaro-Forleo, J Consu Markt. 18(6): 503-520, (2001)

27. M. Pothitou, R. F. Hanna, K. J. Chalvatzis, Appli Energ, 1217-1229, (2016)

28. M. Sanchez, N. López-Mosquera, F. Lera-López, J Environ Pol \& Plan. 1-20, (2015)

29. N. C. Bronfman, P. C. Cisternas, E. López-Vázquez, C. De la Maza, J. C. Oyanedel, Sustain, 7(10): 14133-14152, (2015)

30. N. Singh, K. Gupta, Soc Respon J. 9(1): 4-18, (2011)

31. O. Sapci, T. Considine, J Behav and Exp Econ. 52: 29-34, (2014)

32. P. Díaz-Siefer, A. Neaman, E. Salgado, J. L. Celis-Diez, S. Otto, Sustain. 7: 1551015526, (2015)

33. R. Gaspar, Sustain, 5: 2960-2975, (2013)

34. R. K. Kaufmann, C. Cleveland, Environmental Science. (2007)

35. S. A. Haron, L. Palm, N. Yahaya, Inter J Cons Stud. 29(5): 426-436, (2005)

36. S. D. Clayton, The Oxford Handbook of Environmental and Conservation Psychology. (2012)

37. S. M. Koger, Sustainability. 5: 3006-3008, (2013)

38. S. N. B. Ahmad, N. Juhdi, A. S. Awadz, Intern J Multidis Thoug. 1(11): 328-342, (2010)

39. S. Otto, P. Pensini, Glo Environ Chan. 47: 88-94, (2017)

40. S. P. Robbins, T. A. Judges, Organizational Behavior (Seventeenth Edition). (2017)

41. T. L. Milfont, J. Duckitt, J Environ Psyc. 30(1): 80-94, (2010)

42. United Nations, The World's Cities in 2016. (2016)

43. V. Blok, R. Wesselink, O. Studynka, R. Kemp, J Clean Prod. 1-13, (2014) 